\title{
Verum in Gitksan
}

\author{
LISA MATTHEWSON \\ University of British Columbia, Vancouver, BC, Canada \\ lisa.matthewson@ubc.ca
}

\begin{abstract}
This article provides an analysis of verum marking in the Tsimshianic language Gitksan. Original fieldwork data are provided to show that Gitksan verum is very similar in its distribution and discourse effects to English verum, but displays two interesting differences. First, Gitksan verum is not marked by focal stress, but by a dedicated particle (k'ap). Second, Gitksan verum does not require givenness of the core propositional material. I argue that when applied to a proposition $p, k^{\prime} a p$ is (a) disallowed discourse-initially or in answer to a wh-question; (b) felicitous when responding to a prior assertion or implication of $\neg p$; and (c) felicitous in other contexts only if there is prior controversy in the discourse about the truth of $p$. I show that the semantic contribution of the Gitksan verum particle can be captured by a discourse management analysis: $\operatorname{VERUM}(p)$ is licensed only when the speaker believes that some interlocutor is committed to $\neg p$.
\end{abstract}

Keywords: verum, Gitksan, discourse management, questions, givenness, fieldwork

\section{Résumé:}

Cet article propose une analyse du marquage verum dans la langue tsimshianique gitksan. Des données de terrain originales sont fournies pour montrer que le verum du gitksan est très similaire dans sa distribution et ses effets de discours au verum de l'anglais, mais présente deux différences intéressantes. Premièrement, le verum du gitksan n'est pas marqué par un accent focal, mais par une particule dédiée (k'ap). Deuxièmement, le verum dans gitksan n'exige pas que le matériel propositionnel de base soit donné dans le discours. Je soutiens que lorsqu'il est appliqué à une proposition $p, k^{\prime} a p$ est (a) interdit en position initiale du discours ou en réponse à une question wh; (b) acceptable comme réponse à une affirmation ou à une implication antérieure de $\neg p$; et (c) acceptable dans d'autres contextes seulement s'il y a une controverse préalable dans le discours sur la vérité de $p$. Je montre que la contribution sémantique de la particule de verum du gitksan peut être capturée par une analyse de gestion du discours: VERUM $(p)$ n'est licencié que lorsque le locuteur estime qu'un interlocuteur propose, de façon implicite ou explicite, $\neg p$.

Mots-clés: verum, gitksan, gestion du discours, questions, informations données/donation, travail de terrain 


\section{INTRODUCTION ${ }^{1}$}

The sentence in (1a) is a felicitous way to begin a story, but (1b) is not (with capitalization indicating focal stress). Example (1b) becomes good if embedded in the discourse context in (2).

(1) Context: First line of a story
a. It was a dark and stormy night.
b. \# It WAS a dark and stormy night.

(2) A: Good thing it wasn't a dark and stormy night when you were camping yesterday.

B: It WAS a dark and stormy night.

Following Höhle's (1992) seminal paper, the stressing of the finite verb or auxiliary in specific discourse contexts, as in (2B), is usually called 'verum focus'. Höhle's proposal - developed on the basis of German - is that stress on an element in the left periphery signals focus on a silent VERUM operator, defined as in (3). Focus on this operator serves to emphasize the truth of the proposition.

(3) $[[\operatorname{veRUM}(p)]] \approx$ 'It is true that $p$ '

Many subsequent researchers have debated the correct analysis of verum, often concentrating on data from English and German. ${ }^{2}$ Roughly speaking, two main strands of analysis have been proposed: focus-based analyses (starting with Höhle 1992), and common ground/discourse management-based analyses (with an early major contribution being Romero and Han 2004; see Krifka 2008 on common ground management). In order to avoid committing to a focus-based analysis, I will refer to the phenomenon more neutrally here as 'verum'.

My primary goal in this article is to add to the emerging cross-linguistic empirical landscape with respect to verum. I will present data to show that the Tsimshianic language Gitksan has a verum construction which is strikingly similar to Germanic

\footnotetext{
${ }^{1}$ Heartfelt thanks to Gitksan consultants Vincent Gogag, Jeanne Harris, Hector Hill, Ray Jones, Herb Russell, and Barbara Sennott. Ha'miiyaa! For helpful feedback on this article and on related work, many thanks to the following people: Henry Davis, Daniel Gutzmann, Katharina Hartmann, Jérémy Pasquereau, Hotze Rullmann, Michael Schwan, Neda Todorović, Hubert Truckenbrodt, Malte Zimmermann, three reviewers for CJL, Daniel Siddiqi; members of the Gitksan Research $\mathrm{Lab}$ at UBC, members of the Tense and Aspect in the Pacific Lab at UBC, and audiences at Stanford University, the University of Connecticut, the University of Victoria; the Cross-linguistic Pragmatics Workshop at the Leibniz Zentrum für Allgemeine Sprachwissenschaft, the Eleventh Tbilisi Symposium on Language, Logic and Computation, and the Deutsche Gesellschaft für Sprachwissenschaft (2015 and 2016). This research was supported by the Social Sciences and Humanities Research Council of Canada (grant \#435-2016-0381) and the Jacobs Research Funds.

${ }^{2}$ See for example Hetland 1992a,b; Romero and Han 2004; Büring 2006; Hartmann et al. 2008; Zimmermann and Hole 2008; Gyuris 2009; Leonetti and Escandell-Vidal 2009; Repp 2009, 2013; Schwarz 2010; AnderBois 2011; Gutzmann and Castroviejo Miró 2011; Gutzmann 2012; Lohnstein 2012, 2016, 2018; Stommel 2012; Danckaert 2013; Hartmann 2013; Wilder 2013; Bennett et al. 2015; Romero 2015; Littell 2016; Samko 2016; Goodhue 2018; and Gutzmann et al. 2020.
} 
verum in its distribution and discourse effects. This is in spite of verum being marked in a completely different way in Gitksan than in Germanic, namely by a dedicated particle $\left(k^{\prime} a p\right)$. I will argue that the semantic contribution of the Gitksan verum particle can be captured by a discourse management analysis (see Gutzmann and Castroviejo Miró 2011, Repp 2013). I propose the condition for the Gitksan verum operator in (4). This is informally stated for now, but will be modeled using Commitment Space Semantics (Cohen and Krifka 2014; Krifka 2015, 2017, a.o.) below.

(4) Discourse condition on VERUM $(p)$ :

The speaker believes that some interlocutor is committed to $\neg p$.

This analysis does not involve focus. This is consistent with the fact that Gitksan verum is not marked like any focus phenomena in the language. The analysis also does not require discourse givenness of either $p$ or $\neg p$; we will see that this correctly derives a semantic difference between Gitksan and English verum.

The remainder of the introduction provides background on Gitksan, the particle $k$ 'ap, and the data-collection methodology used. Section 2 presents Commitment Space Semantics and models the discourse condition in (4) within that framework. Section 3, the core of the article, systematically illustrates the discourse properties of the particle $k^{\prime} a p$ and argues that its distribution and function are accurately captured by (4). Section 4 highlights a cross-linguistic difference between English and Gitksan verum, to do with the (non-)importance of givenness. Section 5 compares the proposed analysis to alternatives, and outlines avenues for future research.

\subsection{Introduction to Gitksan and to $\underline{k}^{\prime} a p$}

'Gitksan' (ISO code git) is the English name for an Interior Tsimshianic dialect continuum which is spoken in the northwest Interior of British Columbia, mostly along the Skeena River. Gitksan is classified as 'threatened' by Ethnologue <https://www.ethnologue. com/language/git> and has aproximately 523 fluent speakers (Dunlop et al. 2018).

The Gitksan particle which I will argue encodes verum is $\underline{k}$ 'ap; it is sometimes pronounced $a p$, depending on the dialect. Rigsby (1986:381) classifies $k$ 'ap as a 'preverbal', but does not address its syntax beyond this. My focus here is the semantic contribution of $k^{\prime} a p$, but I provide some brief background on Gitksan clause structure so that the placement of $k^{\prime} a p$ will be transparent.

Gitksan is a head-marking predicate-initial language. The predicate may be preceded by a fronted nominal, as in (5b), by 'dependent markers' and other pre-predicative operators, as in (6), and/or by one or more of over a hundred 'preverbals', as in (7). ${ }^{3}$

\footnotetext{
${ }^{3}$ Gitksan data are given in the orthography developed by Hindle and Rigsby (1973). Glosses follow the Leipzig Glossing Rules where possible, and have in some cases been adapted from prior sources. Additional glosses: $\mathrm{I} / \mathrm{II} / \mathrm{III}=$ series $\mathrm{I} / \mathrm{II} / \mathrm{III}$ pronoun, $\mathrm{AX}=\mathrm{A}$ (transitive subject) extraction, $\mathrm{CCNJ}=$ clausal conjunction, $\mathrm{CIRC}$.NECESS $=$ circumstantial necessity modal, $\mathrm{CN}=$ common noun connective, $\mathrm{DWID}=$ domain widener, $\mathrm{EPIS}=$ epistemic, $\mathrm{HAB}=$ habit, $\mathrm{MANR}=$ manner, $\mathrm{PN}=$ proper noun connective, $\mathrm{PR} . \mathrm{EVID}=$ prior evidence, $\mathrm{PROSP}=$ prospective, $\mathrm{PROX}=$ proximal, $\mathrm{REAS}=$ reason, REPORT $=$ reportative, $\mathrm{SPT}=$ spatio-temporal, $\mathrm{T}=$ ' $\mathrm{T}$ ' suffix, $\mathrm{VAL}=$ valency adjuster, $\mathrm{YNQ}=$ yes-no question. Morphemes which are not pronounced, either through regular morpho-phonological processes or due to speech rate, are given within square brackets.
} 
(5) a. Gyuksxw=hl smax.

wake $=\mathrm{CN}$ bear

'The bear woke.'

b. Smax $=$ hl gyuksxw-it.

bear $=\mathrm{CN} \quad$ wake-sx ${ }^{4}$

'It was a bear that woke.'

(Bicevskis et al. 2017:291)

(6) Hlaa $\mathbf{y u k w}=\mathrm{hl}$ dim maadim.

PROX PROG $=\mathrm{CN}$ PROSP falling.snow

'It can snow any time now.'

(Rigsby 1986:276)

(7) Dim luu tk'al sga t'akw-di-'y 'niin.

PROSP in (up).against blocking lock-CAUS-1SG.II 2SG.III

'I'll lock you up.' (e.g., in jail).

(Rigsby 1986:59)

The preverbals, of which $k$ 'ap is one, 'signify a range of adverbial notions, which include local adverbial, manner, time, and degree concepts' (Rigsby 1986:364b). Their morpho-syntactic status is not clear-cut; Rigsby (1986:58-59) argues that most preverbals are independent words (rather than proclitics or prefixes). in (9).

$K^{\prime}$ ap can appear in declarative sentences, as in (8), and in polar questions, as

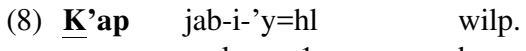

VERUM make-TR-1SG.II $=\mathrm{CN}$ house

'I certainly did build a house.'

(Rigsby 1986:381)

(9) Context: Betty is talking to her husband Adam about their mutual friend Charlie.

B: Siipxw=t Charlie.

sick $=$ PN Charlie

'Charlie is sick.'

(volunteered)

A: K'ap

siipxw=aa?

VERUM sick $=$ YNQ

'Is he really sick?'

(volunteered)

$K^{\prime} a p$ is also marginally acceptable inside wh-questions, and acceptable for some speakers in imperatives. I will mostly set these sentence-types aside, but for some discussion, see section 5.2.

Following Boas's (1911) Tsimshian grammar, Rigsby (1986:381) glosses k’ap as 'certainly, indeed, for sure'. Its counterpart in closely related Nisga'a is glossed by Tarpent (1987:375) as 'absolutely must'; she also gives the translations 'must, have to, absolutely, simply, really, no getting out of it, no two ways about it, no choice about it' (Tarpent 1987:383). In the Sm'algyax Living Legacy Talking Dictionary, the entry for the cognate $\underline{k}^{\prime} a p$ is 'really; certainly; absolutely; intensifier of following predication' <http://web.unbc.ca/ $\sim$ smalgyax $/>.^{5}$ Speakers' English

\footnotetext{
${ }^{4}$ The sx morphology overtly marks extraction (i.e., this is not a nominal predicate construction).

${ }^{5}$ Thanks to Margaret Segun Anderson (p.c.) for drawing this to my attention. The same dictionary also lists a use of $\underline{k}^{\prime} a p$ as a noun-modifier meaning 'essentially'.
} 
translations of $\underline{k}^{\prime}$ ap often contain verum emphasis, as in (10); they may also contain intensifying adverbials, as in (11).

(10) Yugw=imaa ap gwineekw=hl laxha goo=hl Antarctica. PROG $=$ EPIS VERUM cold $=\overline{C N}$ sky $\quad{ }_{\text {LOC }}=\mathrm{CN}$ Antarctica

'Perhaps it IS cold in Antarctica.'

(volunteered without $a p$; consultant's English translation) Consultant's comment: "Only if somebody said it was cold and you sort of doubted it, and [now] you're telling them it really is true."

(11) Ap xatxw 'nii'y.

VERUM cold 1sG.III

'I am really/actually/very cold.'

(volunteered without ap; consultant's English translations)

Consultants frequently offer comments or translations which attempt to convey the contribution of $k$ 'ap. Examples include: 'absolutely'; 'definitely'; 'she's saying that she isn't lying'; 'for sure'; 'a little stressed'; 'if you're defending your statement'; 'quite positive'; 'it's really, actually'; 'a more definite answer'; 'a little more emphatic'; 'not unless you were arguing'; 'an enhancement marker'; 'if you guys are having an argument'; 'when you're speaking in a loud voice'; 'screaming'; 'adamantly'; 'directive'; 'no ifs, ands, or buts'. Such comments give insightful clues about the contribution of $k^{\prime} a p$. The challenge, of course, is to convert these clues into explicit generalizations, and then into an analysis which predicts exactly when $k^{\prime}$ ap is and is not licensed.

\subsection{Methodology}

The data presented here result from the author's fieldwork with six speakers of three dialects. The primary consultants were Barbara Sennott, from Ansba'yaxw (Kispiox), Vincent Gogag, from Git-anyaaw (Gitanyow), Hector Hill, from Gijigyukwhla (Gitsegukla), and Jeanne Harris, from Ansba'yaxw. Data were also elicited from Ray Jones (from Prince Rupert and Gijigyukwhla) and from Herbert Russell (Gijigyukwhla). Readers may notice dialect-based phonological and lexical differences in the data; these do not affect the semantics.

The data were elicited using several fieldwork methodologies: translation tasks (in both directions), elicited production tasks, acceptability judgment tasks, and storyboards. Acceptability judgment tasks involve the consultant evaluating a Gitksan utterance in a specific discourse context, which is presented verbally, sometimes with the help of pictures. Consultants were not given a strict response scale, but simply responded about whether the sentence sounded acceptable in the context. Storyboards involve the presentation of a series of pictures, in response to which the consultant tells a story. The storyboards are designed to elicit specific linguistic phenomena (and thus differ from all-purpose narrative-eliciting techniques such as the Pear Stories (Chafe 1980) or Frog Stories (Berman and Slobin 1994)). See Matthewson (2004), Burton and Matthewson (2015), papers in Bochnak and Matthewson (2015), and Tonhauser and Matthewson (2016), a.o., for further details of these methodologies. 
Since the acceptability of verum is highly sensitive to discourse context, all the data were elicited in controlled contexts. In some cases, the contexts were designed to elicit judgments on discourse-initial utterances. However, an interesting situation arose in these cases, namely that consultants who were presented with a discourseinitial context often enriched the context in their minds. Thus, on several occasions, consultants accepted $k^{\prime}$ 'ap in supposedly discourse-initial contexts, but follow-up questioning revealed that the utterance was in fact only acceptable in an accommodated non-discourse-initial context. These results underline the usefulness of follow-up questioning in one-on-one fieldwork; see Bochnak and Matthewson (2020) for discussion.

A final note is that the expression of verum is not obligatory when it is licensed, in either Gitksan or English. In discourse contexts which license verum, $k^{\prime} a p$ is often, but not always, volunteered. In the data I note when an utterance was volunteered by the consultant. The absence of such an indication on an acceptable utterance means that it was judged as acceptable in the context when the researcher offered it. I do not routinely mark similar information for English translations, but all translations were either offered to the consultant as part of the elicitation prompt, or were volunteered or accepted by the consultant as the translation of the Gitksan utterance.

\section{THEORETICAL BACKGROUND AND PROPOSAL}

Krifka's (2015, 2017) Commitment Space Semantics (see also Cohen and Krifka 2014 ) is designed to deal with the impact on the discourse of various speech acts. It utilizes concepts similar to those used in research on discourse management and dynamic pragmatics, including Gunlogson (2003, 2008); Portner (2004); Farkas and Bruce (2010); Malamud and Stephenson (2015), among many others. The basic concepts of Krifka's framework are commitment states, commitment spaces, and commitment space developments.

The commitment state of a discourse corresponds to the common ground (Stalnaker 1978, a.o.): it contains the set of propositions that are publicly shared by all interlocutors. The commitment space is the set of possible or 'legal' continuations of the current commitment state; it represents the projected future development of the discourse. The commitment space is affected by speech acts performed; for example, if a speaker $S_{1}$ asserts a proposition $p$, all future continuations of the discourse contain the information that $\mathrm{S}_{1}$ is publicly committed to $p$. And commitment space developments are sequences of commitment spaces, representing a record of the conversation, including speech acts that have been performed by each interlocutor. The model thus enables us to keep track of the propositions that each interlocutor has publicly committed to (even if those propositions did not end up being accepted into the commitment state/common ground). For all formal definitions, the reader is referred to Krifka $(2015,2017)$.

Within Commitment Space Semantics, the proposed condition on verum given in (4) (that the speaker believes that some interlocutor is committed to $\neg p$ ) can be 
stated as in (12). The turnstile symbol $\vdash$ indicates public commitment to a proposition. I now also explicitly add information about the truth-conditional effect of the VERUM operator - which is nothing (i.e., vERUM applied to a proposition $p$ simply returns $p$ at the truth-conditional level).

(12) Discourse condition on VERUM ( $p$ ):

The speaker believes that for some $\mathrm{S}_{\mathrm{x}}$, the commitment space development contains $\mathrm{S}_{\mathrm{x}} \vdash \neg p$.

$[[\operatorname{verum}(p)]]=[[p]]$

The claim that VERUM has no effect on the asserted truth conditions is supported by the fact that the contribution of $k$ 'ap can never scope under, for instance, negation, as shown in (13). Lisa's utterance here truth-conditionally conveys that Aidan is not coming; it cannot mean that the speaker does not believe that somebody committed to the belief that Aidan is coming.

(13) Context: Barbara is telling Cheyenne who is coming to work today

Barbara: Dim 'witxw=t Aidan ji hlaa am=hl ga-'nagw-it. PROSP arrive $=$ PN Aidan IRR PROX good $=$ CN DISTR-long-SX 'Aidan will come later.'

(volunteered)

Lisa: Nee, ap nee=m=dii 'witxw-t. Yukw=hl siipxw-t. NEG VERUM NEG $=$ PROSP $=$ FOC arrive-3. II PROG $=$ CN sick-3.II

'No, he ISN'T coming. He's sick.' (volunteered without $a p$ )

Thus, k'ap's contribution is exclusively not-at-issue in the sense of Potts (2005), Tonhauser (2012), a.o., and it is use-conditional (as opposed to truth-conditional) in the sense of Gutzmann (2012).

\section{THE DISTRIBUTION AND FUNCTION OF GITKSAN $K^{\prime}{ }^{\prime} P$}

In this section I test the predictions of the proposal in (12). The data are organized by types of discourse context, as summarized in Table 1. The predictions are sometimes not a matter of simple (un)acceptability. Instead, the core prediction of (12) is that there must be some prior controversy for k'ap to be licensed. This controversy is easily satisfied in cases of correcting a prior assertion or implication of $\neg p$ (rows ii, iii), but is a detectable extra requirement in a range of other contexts (rows iv-viii, and x). $\underline{K}^{\prime} a p$ is straightforwardly ruled out discourse-initially (row i) and in answer to $w h$-questions (row ix), since here, no interlocutor has typically committed themselves to $\neg p$.

\subsection{K'ap does not appear discourse-initially}

As noted by many authors and as shown in (1b) above, verum is infelicitous discourse-initially (see for example Gutzmann and Castroviejo Miró 2011:160, Lohnstein 2012:14). This follows from the condition in (12), because when a proposition $p$ is asserted in a discourse-initial context, nobody has performed any other speech acts yet. Therefore, no interlocutor has committed themselves to $\neg p$. 


\begin{tabular}{|c|c|c|c|}
\hline & DISCOURSE CONTEXT & $\begin{array}{c}S_{\mathrm{X}} \vdash \neg p \text { IN COMMITMENT SPACE } \\
\text { DEVELOPMENT? }\end{array}$ & $\begin{array}{c}\text { PREDICTION FOR } \\
\underline{K}^{\prime} A P\end{array}$ \\
\hline i. & discourse-initially & No & $x$ \\
\hline ii. & after assertion of $\neg p$ & Yes & $\checkmark$ \\
\hline iii. & after implication of $\neg p$ & Yes & $\checkmark$ \\
\hline iv. & after assertion of $p$ & Depends & $\begin{array}{l}\text { Controversy } \\
\text { required }\end{array}$ \\
\hline v. & after implication of $p$ & Depends & $\begin{array}{l}\text { Controversy } \\
\text { required }\end{array}$ \\
\hline vi. & in answer to polar question? $p$ & Depends & $\begin{array}{l}\text { Controversy } \\
\text { required }\end{array}$ \\
\hline vii. & $\begin{array}{l}\text { in answer to indirect polar } \\
\text { question ?p }\end{array}$ & Depends & $\begin{array}{l}\text { Controversy } \\
\text { required }\end{array}$ \\
\hline viii & inside polar question $? p$ & Depends & $\begin{array}{l}\text { Controversy } \\
\text { required }\end{array}$ \\
\hline ix. & in answer to $w h$-question & No & $x$ \\
\hline $\mathrm{x}$. & $\begin{array}{l}\text { in antecedent of a } \\
\text { conditional }\end{array}$ & Depends & $\begin{array}{l}\text { Controversy } \\
\text { required }\end{array}$ \\
\hline
\end{tabular}

Table 1: Discourse contexts and predictions for $k^{\prime} a p$

The prediction that Gitksan $k^{\prime} a p$ is rejected in discourse-initial contexts is upheld, as shown in (14)-(17).

(14) Context: We are sitting working. Michael suddenly says out of the blue:

(\#Ap) ban=hl t'imges-'y.

(\#VERUM) hurt=CN head-1sG.II

'I have/\#HAVE a headache.'

(volunteered without $a p$ )

Consultant's comment on $a p$-version: "No. You would use [(14) with $a p$ ] if you were answering a question, like if I asked 'Have you really got a headache?"”

(15) Context: Out of the blue, I suddenly say to you:

Oo 'nit Vince. (\#K'ap) yee 'nii'y go'o=hl wilb-in.

oh 3.III Vince (\#verum) go 1sG.III LOC=CN house-2SG.II

'Hi Vince. I went/\#DID go to your house.' (volunteered without $\underline{k}^{\prime} a p$ )

(16) Context: Adam and Betty are eating dinner quietly. Nobody has said anything yet. Betty suddenly says:

(\#K'ap) siipxw=t Charlie/Tsaalii.

(\#VERUM) sick=PN Charlie

'Charlie is/\#IS sick.' (volunteered without k'ap; 'Poor Charlie' storyboard)

Consultant 1's comment on $k$ 'ap-version: "Maybe he doubts it and had asked 'Really?' and she says 'Yes, he's really sick."'

Consultant 2's comment on k'ap-version: "It probably came up in the conversation earlier." 
(17) Context: Hector walks into the room and we have some surprising news for him: ${ }^{6}$ (\#吕'ap) yukw=hl dim nek=s Aidan!

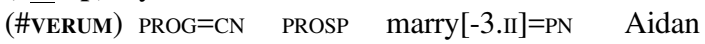
'Aidan is/\#IS getting married!'

(volunteered without $\underline{k}^{\prime} a p$ )

\subsection{K'ap appears following a prior assertion of $\neg p$}

A core use of verum is when a speaker denies a previous utterance. In terms of the condition in (12), VERUM $(p)$ is licensed by the prior assertion of $\neg p$ by a speaker $\mathrm{S}_{\mathrm{x}}$, because that prior assertion updates the commitment space with $\mathrm{S}_{\mathrm{x}} \vdash \neg p$ (Krifka 2015).

This prediction is upheld for k'ap, as shown in (18)-(21). Example (18) is a nearminimal pair with the infelicitous discourse-initial case in (15). Another case of this type was seen in (13). ${ }^{7}$

(18) Context: You're complaining that I didn't go to visit you.
A: Nee=dii 'witxw-in go'o=hl wilb-'y.
NEG $=$ FOC arrive- 2 SG.II LOC $=\mathrm{CN}$ house-1sG.II
'You did not come to my house.'
B: K'ap 'witxw 'nii'y go'o=hl wilb-in=gi.
VERUM arrive 1SG.III $\quad$ LOC $=\mathrm{CN}$ house-2SG.II=PR.EVID
'I DID come to your house.' (volunteered)
(volunteered)

(19) Lisa: $\quad$ Nee $=$ dii $=\mathrm{t} \quad$ hlis-in $[-\mathrm{t}]=\mathrm{s} \quad$ Aidan=hl an-hahla'alji-t.

NEG $=$ FOC $=3 . I \quad$ finish-CAUS[-3.II $=\mathrm{PN} \quad$ Aidan $=\mathrm{CN}$ NMLZ-work-3.II

'Aidan didn't finish his work.'

$\begin{array}{ll}\text { Michael: Ap } & \text { hlis-in-d=ist! } \\ \text { VERUM } & \text { finish-CAUs-3.II=QUDD }\end{array}$

'He DID finish it!'

(volunteered)

(volunteered)

(20) Context: Betty is talking to her husband Adam about their mutual friend Charlie.

B: $\operatorname{Siipxw}(=\underline{\mathrm{ga}}[\mathrm{t}])=\mathrm{t} \quad$ Charlie/Tsaalii.

$\operatorname{sick}(=$ REPORT $)=$ PN Charlie

'Charlie is (reportedly) sick.'

(volunteered)

A: Nee, nee $=$ dii guu $=$ hl siipxw[-t], daxgyet 'nit.

NEG NEG $=$ FOC $\mathrm{HAB}=\mathrm{CN}$ sick[-3.II] healthy 3sG.III

'No, he's not sick, he's perfectly healthy.'

B1: Oo, k’ap lukw'il siipxw [t=]Charlie.

oh VERUM very sick [ $\mathrm{PN}=]$ Charlie

'He IS sick!' (volunteered)

B2: Nee, \#(ap) siipxw $\mathrm{t}=$ Tsaalii=ist.

NEG \#(vERUM) sick=PN Charlie $=$ QUDD

'No, he IS sick!' (volunteered with ap; 'Poor Charlie' storyboard)

\footnotetext{
${ }^{6}$ This example illustrates the elicitation caution raised in section 1.3. The consultant originally accepted the utterance, but when it was uttered in a real-life situation where somebody had just entered the room, he emphatically rejected it.

${ }^{7}$ In (18)-(21), the initial utterance contains negation and the verum utterance does not (i.e., the format is $\neg p$ followed by VERUM $(p)$ ), while in (13), the first utterance is affirmative and the second is negated ( $p$ followed by VERUM $(\neg p)$ ).
} 
Consultant's comment on B2 without ap: "She needs to say Nee, ap siipxwt Tsaalii ist, " because she already said it before and he didn't wanna believe it."

(21) Context: Pearl says to Billy 'Picking you up from the dentist was so funny.'

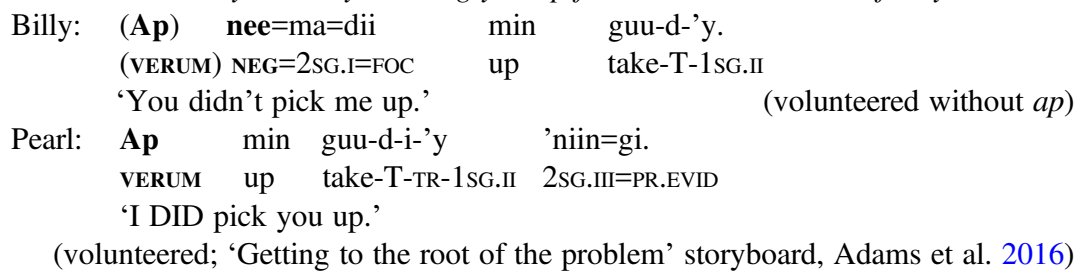

\subsection{K'ap appears following a prior implication of $\neg p$}

The proposed analysis is that $k^{\prime} a p$ requires the speaker to believe that some interlocutor is publicly committed to the negation of $p$. Within Krifka's (2015) system, implicatures become part of an interlocutor's set of public commitments: Krifka diagrams a case where a conversational implicature is reflected in the commitment space development (his Figure 6). The same would reasonably hold for presuppositions of utterances; they become public commitments of the speaker.

This predicts that VERUM $(p)$ can be used to correct not just a prior assertion of $\neg p$, but also a previous implication that $\neg p$. This is correct; Gitksan speakers frequently volunteer $\underline{k}$ 'ap in such contexts. In some cases below, I remain agnostic about exactly what kind of implication is involved (presupposition, conversational implicature, or conventional implicature), because Gitksan-internal tests have not been done to tease these apart.

We begin with (22). Assuming that Gitksan wh-questions have discourse effects similar to English ones, the relevant implication here (that Aidan isn't coming) is probably a presupposition. ${ }^{8}$

(22) Context: Working at UBC Linguistics.

$\mathrm{R}$ : 'Nidee Mike. Oo gu gan wi[l][-t]=hl nee=dii 'witxw[-t $]=\mathrm{s}$ Aidan

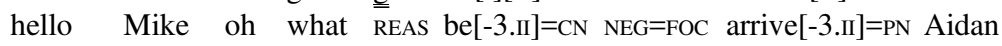
sa tun?

day DEM.PROX

'Hello Mike. Why isn't Aidan coming today?'

(volunteered)

M: Dim ap 'witxw 'nid=is.

PROSP VERUM arrive 3.III $=$ QUDD

'He IS coming.'

(volunteered)

Another presupposition denial case is (23). The felicity of $\underline{k}^{\prime} a p$ is predicted by the analysis. Interestingly, verum marking is not good in English in this environment.

\footnotetext{
${ }^{8}$ Example (22) speaks against an earlier analysis of Gitksan VERUM ( $p$ ) according to which the question whether $p$ must be the maximal Question Under Discussion (Gutzmann et al. 2016; see also Gutzmann and Castroviejo Miró 2011 for Germanic). The question in (22) is not whether Aidan is coming, yet $k^{\prime} a p$ can target this proposition.
} 
In section 4 we will see that this reflects a difference between the languages in terms of givenness requirements on verum. ${ }^{9}$

$\begin{array}{lllll}\text { (23) Lisa: } & \text { Hets'imox } & \text { sii neks } & {[\mathrm{t}=] \text { Mary. }} & \\ & \text { again } & \text { new marry } & {[\mathrm{PN}=] \text { Mary }} & \text { (volunteered) } \\ & \text { 'Mary got married again.' } & & \\ \text { Sharon: } & \text { K'ap } & \text { nee=dii neks-t } & \text { hligook! } \\ & \text { VERUM } \quad \text { NEG=Foc marry-3.II } & \text { before } & \\ & \text { 'She wasn't married before!' } & & \end{array}$

The data in (24)-(25) involve denials of implications which arise from the Gitksan counterparts of 'pretend' and 'promise'.

(24) A: Siipxw-good-'y a $\mathrm{a}$ s Charlie, his siipxw-t. sick-heart-1SG.II PREP=PN Charlie pretend sick-3.II

'I'm mad at Charlie, he is pretending to be sick.' (volunteered)

B1: K'ap siipxw 'nid=is.

VERUM sick 3SG.III-QUDD

'He IS sick.'
B2: \#(K'ap) siipxw=t Charlie(=is).
\#(VERUM) sick=PN Charlie $(=$ QUDD $)$
'Charlie IS sick.'

(volunteered)

Consultant's comment on B2 without k'ap: "You need that little emphasis, $k$ 'ap."

(25) Context: We were waiting for Michael, who specifically promised to come today.

Ee'eesxw Michael dim kw'itxw-t ii ( $\left.\mathbf{k}^{\prime} \mathbf{a p}\right)$ nee=dii kw'itxw-d=is. promise Michael PROSP arrive-3.II CCNJ (VERUM) NEG=FOC arrive-3.II=QUDD 'Michael promised to come, but he didn't come.' (volunteered without $\underline{k}^{\prime} a p$ )

In (26), A's utterance generates the implication that Peter is not a white guy, because if A had known that Peter was a white guy, s/he would have said so (by ordinary Quantity Maxim effects), rather than merely talking about what Peter thinks. B corrects this implication using $k^{\prime} a p$.
A: Ha-'nii-goot[-t]=s Peter ji amxsiiwaa-t.
INS-on-heart[-3.II]=PN Peter IRR white.person-3.II
'Peter thinks he's a white guy.'
B: Ap amxsiiwaa 'nid=ist.
VERUM white.person 3SG.III=QUDD
'He IS a white guy.'

(volunteered)

Cases where a speaker talks about their own beliefs often give rise to the implication that the embedded proposition is true (see Hacquard and Lidz 2018, a.o., for the observation that belief reports are often used to make indirect assertions). We see this in (27) and (28), which involve respectively a matrix belief predicate and an epistemic modal (the inferential evidential =ima'; Peterson 2010, Matthewson 2013).

\footnotetext{
${ }^{9}$ An anonymous reviewer makes an interesting observation about German here: while a direct German translation of (23) is infelicitous, verum becomes acceptable in the reply if we add the discourse particle überhaupt (which is frequently used in responses to presupposition failure). I am not aware of any additional elements which can save verum marking in English for examples like (23).
} 
The implication in both cases is corrected using $\underline{k}^{\prime} a p$. These contexts are adapted from Zimmermann and Hole (2008).

(27) Lisa:

$$
\begin{aligned}
& \text { Ha-'nii-good-'y nee=dii hlis-in[-t]=s } \\
& \text { INS-on-heart-1sG.II NEG=FOC finish-CAUS[-3.II]=PN } \\
& \text { ji dim jab-i-t. } \\
& \text { IRR PROSP do-TR-3.II } \\
& \text { 'I think Arian didn't finish the work he had.' }
\end{aligned}
$$

Arian $=\mathrm{hl}$ hahle'els

Arian $=\mathrm{CN}$ work

(volunteered)

Clarissa: (K'ap) hlis-in-d=is.

(VERUM) finish-CAUS-3.II=QUDD

'He DID finish it.'

(volunteered without $k^{\prime}$ 'ap; English translation volunteered for $k^{\prime}$ 'ap version)

(28)
$\mathrm{Nee}=$ dii $=\mathrm{t} \quad$ hlis-in $[-\mathrm{t}]=\mathrm{s}$
Michael ahle'els-d=ima'.
$\mathrm{NEG}=\mathrm{FOC}=3 . \mathrm{i}$ finish-CAUS[-3.II] $=\mathrm{PN}$
Michael work-3.II=EPIS
'Michael might/must not have finished his work.'
(volunteered)
Henry: Nee, k'ap hlis-in-t ahle'els-t.
NEG VERUM finish-CAUS=3.II work-3.II
'No, he DID finish his work.'
(volunteered)

The example in (29) is similar, but involves negation in the matrix clause. The utterance of 'I don't think $p$ ' gives rise to the implication $\neg p$, which the second speaker corrects using verum.

(29) Context: We're wondering about whether Aidan finished his work.
Lisa: Nee=dii ha-'nii-good-'y ji=t hlis-in[-t $\mathrm{t}=\mathrm{hl}$
NEG $=$ FOC INS-on-heart-1 1 G.$I I \quad$ IRR=3.I finish-CAUS[-3.II $]=\mathrm{CN}$
'I don't think he finished his work.'
hahla'alji-t.
work-3.II
(volunteered)
Henry: Ap hlis-in-d=ist.
VERUM finish-CAUS-3.II=QUDD
'He DID finish it.'
(volunteered)

A final interesting case involves a silent implication of $\neg p$. Barbara's accusing body language is sufficient to commit her to the implication that Lisa took the cookie.

(30) Context: The last cookie is missing from the cookie jar.

$\begin{array}{llll}\text { Barbara: } & \text { Oo 'niin an=t jahl[-t] }(=\mathrm{hl}) & \text { guugiis=aa? } & \text { Lisa: Nee. } \\ & \text { oh 2sG.II AX=3.I eat.up[-3.II }(=\mathrm{CN}) & \text { cookie=YNQ } & \text { NEG } \\ & \text { 'Did you eat the last cookie?' 'No.' } & & \text { (volunteered) }\end{array}$

Barbara: Raises eyebrow (as if to silently accuse Lisa).
Lisa: Nee! Ap nee $=$ dii $=\mathrm{n}$ jahl[-t] $(=\mathrm{hl})$ guugiis.
NEG VERUM NEG=FOC=1SG.I eat.up[-3.II] $(=\mathrm{CN})$ cookie

'No! I DIDN'T eat the cookie.'

(volunteered)

\subsection{Following a prior assertion of $p$ : Controversy required}

According to the proposed analysis, verum requires the speaker to believe that some interlocutor is committed to the negation of $p$. This predicts that VERUM ( $p$ ) will not straightforwardly be felicitous following a prior assertion of $p$ itself. However, verum should become possible in such cases if there is controversy about the status of $p$ amongst the interlocutors. This leads to the effect of emphatic agreement. Examples are given in (31)-(32). In (32), the first utterance already contains $k^{\prime} a p$; the 
first speaker is saying 'It's true that ...', thus implicitly responding to some controversy in the context.

(31) Context: Katie is eight months pregnant and we are wondering how she is doing.
A: $\quad A m=h l$ wila jab-i[-t] $=\mathrm{s} \quad$ Katie ky'oots.
good $=\mathrm{CN}$ MANR make-TR[-3.II]=PN Katie yesterday
'Katie was looking good yesterday.'
(volunteered)
B: Ee, k'ap lukw'il am.
yes verum very good
'Yes, she WAS looking very good.'
(volunteered)

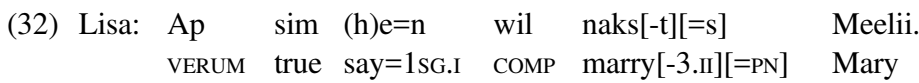
'It's true that Mary got married.' (volunteered)
Barbara: Ee'aa, (ap) naks-t Meelii.
yes (verum) marry-3.II Mary
'Yes, she got/DID get married.'
(volunteered without $a p$ )

Consultant's comment on Barbara's reply: " $A p$ is really, she actually."

It is difficult to prove conclusively that prior controversy is needed for $k^{\prime} a p$ to be acceptable in cases of agreement with a prior utterance. However, I claim that the facts in Gitksan are similar to those in English. For English, Repp (2013:28-29) argues that 'VERUM cannot be used to affirm the proposition that was uttered by the previous speaker if not uttered in a [...] more complex discourse.' Repp gives (33) as an example, stating that (33B) is felicitous only if the question whether Paul had a banana was at issue well before A's utterance.

(33) A: Paul had a banana.

B: \#(Yes.) Paul DID have a banana.

(Repp 2013: 29)

The claim that controversy is required to license verum in agreement cases is supported by the fact that over many elicitation sessions with each consultant, none has volunteered $k^{\prime} a p$ in a context where a speaker is simply confirming what a previous speaker has said. $K^{\prime} a p$ is often judged as less than perfect in contexts of agreeing, as in (34), and comments like the one in (35) further support the idea that controversy in the context is required.

(34) Context: All the students are having a party to celebrate the end of term. Henry is not there.

Aidan: Lukw'il nee $=$ dii $a m[-t]=s$ Henry $\mathrm{a}=\mathrm{hl}$ sii gyu'un.

very NEG=FOC good[-3.II] $=\mathrm{PN}$ Henry $\mathrm{PREP}=\mathrm{CN}$ new now

'Henry has been very bad lately.'

Katie: Ee'aa, (?ap) lukw'il nee=dii am-t.

yes (?verum) very NEG=FOC good-3.II

'Yes, he has been very bad.' （volunteered without $a p$ )

Consultant's comment: "I think it's better if you say [similar sentence without $a p$ ]."

(35) Michael: Helt=hl jab-'m sa tun.

much $=$ CN do-1PL.II day DEM.PROX

'We got a lot done today.'

(volunteered) 


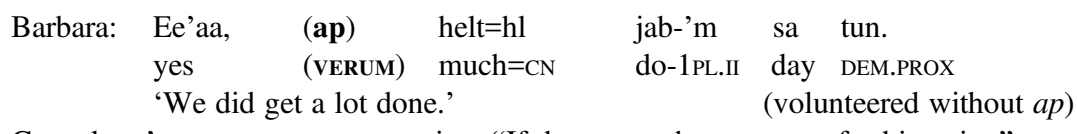

Consultant's comment on ap-version: "If the person has to argue for his point."

Example (36) is an interesting case where the speaker himself is the person who provides the controversy, by having previously been committed to $\neg p$ and then changing his mind. Billy can naturally be assumed to have believed (before Pearl's utterance) that his shirt was not on backwards.

(36) Pearl: Guks=hooy[-i] $-\mathrm{n}=\mathrm{hl}$ backwards $=$ use $[-\mathrm{TR}]-2 \mathrm{sG} . \mathrm{II}=\mathrm{CN}$ 'Your shirt is on backwards.' khla'wsxw-in.

shirt-2sG.II

(volunteered)

oh VERUM backwards=use[-TR]-1sG.II

'Oh, it IS on backwards!'

(volunteered; 'Getting to the root of the problem' storyboard, Adams et al. 2016)

This example is interesting from the point of view of the proposed analysis, because it is not the case that Billy (or anybody else) has publicly committed to the negation of his utterance's prejacent (that his shirt is on correctly). ${ }^{10}$ The issue of how exactly 'commitments' should be defined within Commitment Space Semantics is a larger question which I cannot solve here; however, examples like (36) might suggest that commitments can exist without having been explicitly uttered. This would fit with Krifka's (2015) idea that the commitment state corresponds to the common ground, since it is standardly assumed that propositions can be in the common ground without having been uttered by any interlocutor.

This raises a further question, however. If a speaker's internal beliefs can count as commitments without having been publicly uttered, what then distinguishes (36) from the 'out-of-the-blue' cases discussed in section 3.1, where $k^{\prime} a p$ is resoundingly rejected?

The first step to answering this is to consider whether discourse-initial $k^{\prime} a p$-utterances can be rescued by virtue of the speaker having previously believed the opposite. The answer is 'no': speaker surprise by itself does not license verum. This is shown by (37), which differs from (36) only in that the k'ap-utterance is discourse-initial:

(37) Context: You are out walking with a friend and you suddenly notice that your shirt is on backwards. You say:

(\#K'ap) guks=hooy[-i]-'y=hl

(\#VERUM) backwards=use[-TR]-SG.II $=\mathrm{CN}$

'My shirt is on backwards!'

khla'wsxw-'y!

shirt-1SG.II

(volunteered with $k^{\prime} a p$ )

Consultant's comment on k'ap-version: "It's a bit awkward. I don't think you'd use k'ap there. Doesn't work."

I interpret these facts as follows. First, propositions can count as interlocutor commitments without having been explicitly uttered, but this is only possible for

\footnotetext{
${ }^{10}$ Thanks to an anonymous reviewer for pointing this out, as well as for raising the question in the next paragraph.
} 
very obvious, general-knowledge propositions (such as that shirts are usually worn frontwards); it is not possible for random propositions about individuals, such as that Michael doesn't have a headache or that Charlie is healthy (see (14) and (16) above). In addition, there really must be some controversy in the discourse context for verum to be felicitous. This is not the case in (37), but it is arguably the case in (36).

\subsection{Following a prior implication of $p$ : Controversy required}

We saw in section 3.3 that implications of utterances can count as public commitments by interlocutors. Here we look at cases where a prior utterance implies $p$. The prediction - as with prior assertion of $p-$ is that $k^{\prime} a p$ should be felicitous only if there is reason to believe that an interlocutor is committed to the negation of $p$. This is what I have been calling the controversy requirement. ${ }^{11}$

A clear case where verum should be infelicitous, because there is no controversy, is when a speaker agrees with the presupposition of a prior utterance. Presuppositions are taken to be assumed by all interlocutors, hence nobody can be committed to their negation. As predicted, $\underline{k}^{\prime} a p$ is bad when agreeing with a presupposition, as shown in (38).

$$
\begin{aligned}
& \text { A: Hets'imox neks[-t] Mary. } \\
& \text { again marry[-3.II] Mary } \\
& \text { 'Mary got married again.' } \\
& \text { B: Ee, (\#- } \\
& \text { yes (\#VERUM) before marry 3.III=PR.EVID } \\
& \text { 'Yes, she was/\#WAS married before.' (volunteered without } \underline{k} \text { 'ap) }
\end{aligned}
$$

The controversy requirement is further supported by cases like (39); the reference to 'trying to convince' someone suggests that the implication that Mark finished his work is controversial.
A: Ha-'nii-good-'y ji hlisxw[-t $]=s$ INS-on-heart-1sG.II IRR finish[-3.II]=PN 'I think Mark finished his work.'
$\begin{array}{lll}\text { Mark } & \mathrm{a}=\mathrm{hl} & \text { ahle'els-t. } \\ \text { Mark } & \text { PREP }=\mathrm{CN} & \text { work-3.II }\end{array}$
yes (VERUM) finish-CAUS-3.II=QUDD
'He DID finish it.'
B: Ee, (k'ap) hlis-in-d=is.

\begin{tabular}{|c|c|c|c|}
\hline & & 'witxw-t, & \\
\hline
\end{tabular}
(volunteered without $k^{\prime} a p$ )
Consultant's comment on $\underline{k}$ 'ap-version: "Meaning yes, he actually did this. That little subtle word that you put in there, that $k^{\prime} a p$, now you're trying to convince that person."

The example in (40) was given by three separate speakers with only minor irrelevant differences. All three speakers volunteered the sentence with $\underline{k}$ 'ap.

(40) Context: We are expecting Aidan and he hasn't shown up yet.

\footnotetext{
${ }^{11}$ In this prediction I disagree partially with Zimmermann and Hole (2008); they state that verum can be used when confirming 'a supposed/expected path of events.' I argue that there must be controversy in the broader context.
} 
'He promised to come, and he WILL come.'

(volunteered; adapted from Zimmermann and Hole 2008)

Promise ( $p$ ) can often be taken to implicate $p$ (see discussion of (25) above), so our analysis predicts that (40) should only be licensed if there is additional controversy about $p$ in the context. Indeed, in the context for (40), the promise looks likely to be unfulfilled (since Aidan has not shown up). This is supported by the fact that one speaker, upon rejecting this sentence with $\underline{k}$ 'ap removed, commented "No, it needs the ap. Because you're making reassurances." If the speaker is reassuring the addressee that Aidan will come, this suggests that the addressee believes he isn't coming.

\subsection{In answers to polar questions: Controversy required}

$K^{\prime} a p$ is felicitous inside answers to polar questions, but only in a subset of discourse contexts; verum cannot be used if the question is neutral or unbiased. Correspondingly, there is always a perceived emphatic effect when verum is used in the answer.

Example (41) shows that $\underline{k}^{\prime} a p$ is rejected in a context where an expected or uncontroversial answer is given.

(41) Context: We are going to the movies. You often come with us when we go.

Me: Hasak-n dim sdil-i'm=aa?

want-2SG.II PROSP accompany-1PL.II=YNQ

'Do you wanna come with us?'

You: (\#Ap) dim huksxw 'nii'y.

(\#VERUM) PROSP be.with 1SG.III

'I'll come.' (\# I WILL come.) (volunteered without ap)

Consultant's comment on ap-version: "I AM going to go. It's more emphasis that, hell or high water, you won't be left behind."

Another consultant provides (42) for this conversation; again, the comment on the $k^{\prime}$ ap-version reveals that verum marking requires a context with controversy. In support of this, the consultant for (42) freely accepts, without the need for any commentary, $k^{\prime} a p$ in the reply in a more controversial context, in which my friends and I go to the movies every Friday but you've never come along before.

(42) Context: We are going to the movies. You often come with us when we go.

Me: $\mathrm{Nee}=\mathrm{mi}=\mathrm{dim} \quad$ sdil-i'm $=\mathrm{aa}$ ?

NEG $=2$ SG.I $=$ PROSP accompany-1PL.II $=$ YNQ

'Will you come with us?'

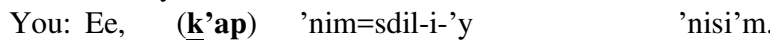

yes (VERUM) want=accompany-TR-1SG.II 2PL.III

'Yeah, I'll /I WILL come.' (volunteered without $k$ 'ap)

Consultant's comment on $\underline{k}^{\prime} a p$-version: "If you know the person sometimes says yes and then changes his mind, the $\underline{k}$ 'ap will do away with the thought that he might not." 
Example (43) provides another case showing that $\underline{k}^{\prime} a p$ is rejected in the answer to a neutral polar question.

(43) Context: Our friend Paul has been advised by the doctor to eat fruit for his health.
A: $\mathrm{Nee}=\mathrm{t}$ $\operatorname{gup}[-\mathrm{t}]=\mathrm{s}$
Paul=hl
maa'y
berry
NEG $=3 . I$
eat $[-3 . \mathrm{II}]=\mathrm{PN}$
rries yesterday?
'Did Pa
Paul $=\mathrm{CN}$
B: \#Ee, ap maa'y=hl gub-i-t ky'oots. yes VERUM berry $=\mathrm{CN}$ eat-TR-3.II yesterday
'Yes, he DID eat berries yesterday.'

$\mathrm{ky}^{\prime}{ }^{\circ o j=a a}{ }^{12}$

yesterday $=\mathrm{YNQ}$

(volunteered)

\subsection{In answers to indirect polar questions: Controversy required}

Zimmermann and Hole (2008) observe that verum can be used in answers to indirect or implicit polar questions. This is also the case for k'ap, as shown in (44)-(45). In (44), the implicit question is 'Is Henry coming today?' and in (45), it is 'Did Charlie steal my purse?'

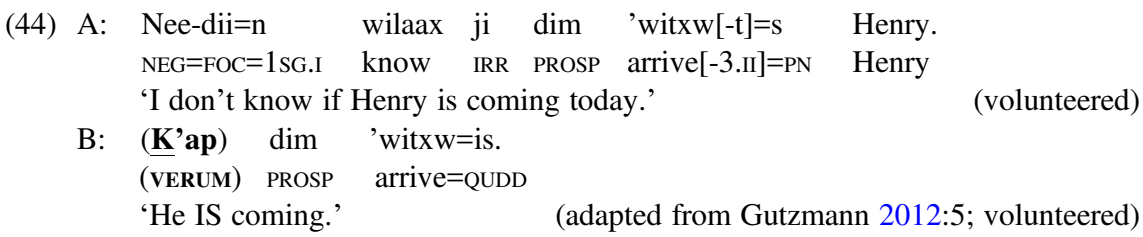
Consultant's comment on $\underline{k}$ 'ap-version: "You know for sure."

(45) Context: Lisa notices that her purse is missing, and Charlie is one of her suspects.

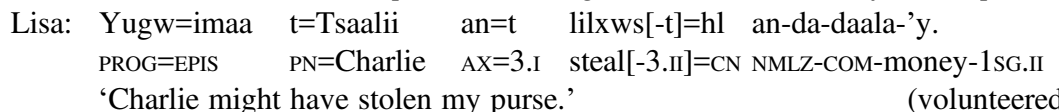

Barbara1: Nee, (ap) nee $=$ dii 'nit ji an=tli lxws-d=ist.

NEG (VERUM) NEG=FOC 3.III IRR AX=3.I steal-3.II=QUDD

'He DIDN'T steal it.' (lit.: 'It WASN'T him who stole it.')

(volunteered without $a p$ )

$\begin{array}{rlll}\text { Barbara2: (Ap) } & \text { 'nit } & \text { an }=\mathrm{t} & \text { lilxws-d }=\text { ist. } \\ \text { (VERUM) } & \text { 3.III } & \mathrm{AX}=3 . \mathrm{I} & \text { steal-3.II }=\mathrm{QUDD}\end{array}$

'He DID steal it.' (lit.: 'It WAS him who stole it.') (volunteered without ap)

The analysis predicts that the verum answers in (44)-(45) will only be felicitous if there is some controversy in the context, beyond the immediately preceding utterances. Example (44) is particularly interesting because while the prejacent propositions of Barbara's utterances entail the negation of an earlier public commitment, they do not equal the negation of that prior commitment. Lisa is publicly committed to the proposition that Charlie might have stolen her purse (because she asserts this), and is also committed to the proposition that he might not have stolen it (because she implies this, due to her failure to simply assert that he did steal it). Barbara's answers

\footnotetext{
${ }^{12}$ Polar questions by default contain negation in Gitksan (Rigsby 1986:296). However, this crucially does not convey the same epistemic bias as negated polar questions in English (Romero and Han 2004); see Matthewson (2019).
} 
entail the negation of these two prior commitments respectively, but they do not strictly have the form of their negations.

Although it is, again, difficult to prove conclusively the controversy requirement, there is some evidence for it. Consider (46), for example, where the implicit question in the context is 'Who punched the dog?' The consultant's comment suggests that a neutral context is not sufficient to license verum. $K^{\prime}$ ' $a p$ requires the speaker to believe that he needs to defend his innocence.

(46) Context: Two people walk in to see that their dog is badly injured.

(K'ap) nee-dii=n t'is[-t] $=\mathrm{hl} \quad$ os $=$ is.

(VERUM) $\mathrm{NEG}=\mathrm{FOC}=1 \mathrm{SG} . \mathrm{I} \quad$ hit[-3.II] $=\mathrm{CN} \quad \mathrm{dog}=\mathrm{QUDD}$

'I didn't/DIDN'T punch the dog.'

(volunteered without $k^{\prime} a p$ )

Consultant's comment on k'ap-version: "If she's accusing him, he could say that."

\subsection{Inside polar questions: Controversy required}

K'ap can appear inside polar questions, but not in neutral contexts. This is shown in (47)-(49). In (48)-(49), two consultants gave similar judgments, while a third speaker simply rejected $k^{\prime} a p$ in this non-controversial context.

(47) K’ap siipxw=aa?

VERUM sick $=$ YNQ

'IS she sick?'

(volunteered)

Consultant's comment: "If you're looking at her and she's looks healthy, and you doubt it, you could say [(47)]."

(48) Context: We are going to the movies. You often come with us when we go. I ask you: \# Ap hasag-an dim sdil-i'm=aa?

VERUM want-2SG.II PROSP accompany-1PL.II=YNQ

'Do you really want to go with us?'

Consultant's comment: "No, if I usually come to the movies with you guys. Ap hasagan, it's kinda a one-time thing, it's kinda unusual for me to come along... you're asking me if I really want to go."

(49) Context: We are going to the movies. You often come with us when we go. I ask you: (Ap) nee=hl hasag-an mi $=$ dim sdili'm $=a a$ ? (VERUM) NEG=CN want-2SG.II 2.I=PROSP accompany-1PL.II $=$ YNQ

'Do you (really) want to go with us?'

(volunteered without $a p$ )

Consultant's comment on k'ap-version: "It might sound a little like an un-invite to a Gitksan person, if she usually goes with them anyway."

In (50), question-internal $k^{\prime} a p$ is rejected in a non-controversial context, and in (51), k'ap's controversy requirement is captured by the comment, which suggests that the question is uttered aggressively.

(50) Context: Aidan was missing all day.

Michael:

Oo, ksi-wa-'y=hl

$\mathrm{gu}=\mathrm{hl} \quad \mathrm{jab}-\mathrm{i}=\mathrm{s}$

what $=\mathrm{CN}$ make-TR $=\mathrm{PN}$

Aidan 'wii sa.

oh out-find-1sG.II $=\mathrm{CN}$

Aidan big day

'I found out what Aidan was doing all day.'

(volunteered)

Lisa: yukw jam[-t]=hl

wineex $=\mathrm{a} a$ ?

(\#VERUM) PROG $\operatorname{cook}[-3 . \mathrm{II}]=\mathrm{CN}$ food $=$ YNQ

'Was/\#WAS he cooking?'

(volunteered without $\underline{k}^{\prime} a p$ ) 
(51) Context (translated from Gitksan): A: Katie's baby got lots of presents. B: From who? A: From Aidan, Michael, Kyra and Henry.

B: Oo, k'ap gi'nam-i[-t] $=\mathrm{s}$ Aidan ligi agu loo-d=aa? oh VERUM give-TR[-3.II]=PN Aidan DWID what OBL-3.II=YNQ

'Did Aidan really bring her something?'

(volunteered; adapted from Romero and Han 2004:625) Consultant's comment: "Now this is in their face. You're going like this" (acts putting face close to addressee, big eyes).

In (52), there is controversy because B is skeptical that Bellingham is the capital of Washington (because, of course, Olympia is).
A: Mahl-d-i[-t] $=\mathrm{s}$
T.J. win Bellingham
hla-miinimts'ep
Washington. say-T-TR[-3.II] $=$ PN
T.J. ComP Bellingham NMLZ-capital
Washington
'T.J. said that Bellingham is the capital of Washington.'
(volunteered)
B: K'ap Bellingham hla-miinimts'ep=hl Washington=aa?
VERUM Bellingham NMLZ-capital $=\mathrm{CN} \quad$ Washington $=\mathrm{YNQ}$
'IS Bellingham the capital of Washington?'
(volunteered; adapted from Gutzmann and Castroviejo Miró 2011:162)

In terms of analysis, I assume that k'ap has its normal use-conditional effect, even when the prejacent is being questioned (see Repp 2013, Romero 2015). ${ }^{13}$ I further assume a standard view that the denotation of polar questions is the set of possible answers: $\{p, \neg p\}$. I then adopt ideas by Davis and McCready (2016) about expressives (use-conditional elements) in questions, following Gutzmann et al. (2020) for their application to verum. Davis and McCready argue that expressives in questions can operate on whatever is the true answer to the question. This idea predicts that speakers can use $k$ 'ap inside a polar question if they believe that somebody (presumably usually the addressee) is committed to the false answer. In (52), for example, B believes A is committed to the false proposition that Bellingham is the capital of Washington.

\subsection{Verum does not appear in neutral answers to $w h$-questions}

The analysis predicts that $k^{\prime}$ ap cannot be used in an answer to a $w h$-question, since in ordinary contexts in which a wh-question is asked, no discourse participant is committed to one particular answer to the question. ${ }^{14}$ This is noted also by Leonetti and Escandell-Vidal (2009) for Spanish and by Gutzmann and Castroviejo Miró (2011) for German. The following data show that Gitksan speakers either reject $k$ 'ap in answer to a wh-question, or offer comments indicating that prior controversy is required.

\footnotetext{
${ }^{13}$ Romero (2015) and others have already argued against an alternative idea whereby the contribution of verum semantically scopes inside the question. In our case, that alternative would incorrectly predict that the speaker of (52) is asking whether the addressee believes that some interlocutor is committed to the proposition that Bellingham is not the capital of Washington.

${ }^{14}$ The data in section 3.3 with verum in the answer to a wh-question (example (22)) was different; there the answer was denying the presupposition of the question, rather than answering it.
} 
(53) Context: Michael is telling Katie that he has a pet called Fluffy. Katie wonders what kind of animal Fluffy is, so she asks Michael, 'What IS Fluffy?'

Michael: (\#K'ap) lelt/lalt=t Fluffy(=ist).

(\#vERuM) snake=PN Fluffy $(=$ QUDD $)$

'Fluffy is/\#IS a snake.'

(volunteered without $k^{\prime} a p$ )

Consultant 1's comment on k'ap-version: "No. it would just be Lalt Fluffy ist. And then if she doubts it, he can say Ap lalt Fluffy ist."

Consultant 2's comment on $k^{\prime} a p$-version: "No. Not unless you start arguing and then you say Oo, k'ap lelt."

(54) Context: Billy was unaware of his actions yesterday due to drugs from the dentist.
Billy: Gwi=hl gub-i-'y=gi?
what $=\mathrm{CN}$ eat-TR-1 $\mathrm{sG} . \mathrm{II}=\mathrm{PR} . \mathrm{EVID}$

'What did I eat?"

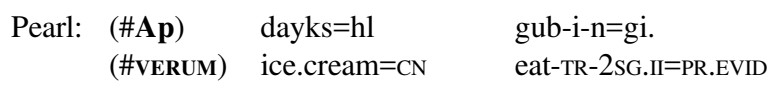

'You ate ice cream.'

(volunteered without ap; 'Getting to the root of the problem' storyboard, Adams et al. 2016)

(55) Lisa: Naa=hl sil hahla'lsd-i-n sa tun?

who $=$ CN COM work-TR-2SG.II day DEM.PROX

'Who did you work with today?'

Vince: (\#K'ap) sil hahla'als-xw-i-’y t=Aidan.

(\#VERUM) COM work-VAL-TR-1SG.II PN=Aidan

'I worked with Aidan.'

(volunteered without $\underline{k}^{\prime} a p$ )

\subsection{In antecedent of a conditional: Controversy required}

According to Zimmermann and Hole (2008), verum in the antecedent of conditionals 'stress[es] the conditionality'; their example involves a situation where the truth of the antecedent is doubted. This characterization also appears to be true of $k^{\prime} a p$, as shown in (56)-(57).

(56) Context: You think Aidan probably won't come.

$\begin{array}{cllllll}\text { Ji daa } & \text { ap } & \text { 'witxw[-t]=s Aidan, dim ii ha'w-'y, } & \text { ii ap } \\ \text { IRR SPT } & \text { VERUM } & \text { arrive[-3.II]=PN Aidan PROSP CCNJ } & \text { go.home-1sG.II CCNJ VERUM } \\ \text { nee=dii } & \text { ha'niigood-'y dim 'witxw-t. } & & \\ \text { NEG=FOC } & \text { think-1sG.II } & \text { PROSP } & \text { arrive-3.II } & \text { (volunteered without } a p \text { ) }\end{array}$

'IF Aidan comes, I will leave, but I don't think he will come.'

Consultant's comment on ap-version: "There's a little more emphasis on the 'if'."

(57) Billy: Ji daa daxgyad-'y t'aahlakw, nee=hl am ji-n gup[-t]=hl

IRR SPT strong-1SG.II tomorrow $\mathrm{NEG}=\mathrm{CN}$ good IRR-1sG.I eat[-3.II] $=\mathrm{CN}$ dayks $=\mathrm{aa}$ ?

ice.cream $=\mathrm{YNQ}$

'If I'm strong enough tomorrow, can I have some ice cream?' (volunteered)

Pearl: (Ap) ji daa mootxw-in t'aahlakw, ii mi dim gup[-t]=hl dayks. (VERUM) IRR SPT cure-2SG.II tomorrow CCNJ 2SG.I PROSP eat[-3.II] $=\mathrm{CN}$ ice.cream 'IF you're better tomorrow, you can have some.' (volunteered without ap; 'Getting to the root of the problem' storyboard, Adams et al. 2016) 
As noted by Romero (2015), among others, conditional antecedents have a parallel with interrogatives; if $p$ signals that the question of whether $p$ is true is an open issue. We can apply the same approach to conditional antecedents containing $k^{\prime}$ 'ap as we did for polar questions in the previous section: in (57), for example, Pearl believes that the false answer to the question (whether Billy will be better tomorrow) is in someone's commitment slate (namely, Billy's).

\subsection{Summary}

Throughout this core section of the article, we have seen that Gitksan $\underline{k}$ 'ap is felicitous whenever the speaker believes that the negation of the prejacent proposition is in some interlocutor's commitment slate. This correctly predicts that $k$ 'ap is disallowed discourse-initially and in answer to a wh-question, straightforwardly felicitous after assertion or implication of $\neg p$, and acceptable in all other contexts only if there is prior controversy about the truth value of $p$. The results are in accord with the predictions laid out in Table 1 at the beginning of this section.

\section{A CROSS-LINGUISTIC DIFFERENCE: THE (NON-)IMPORTANCE OF GIVENNESS}

In this section I report on a difference between Gitksan $\underline{k}$ 'ap and English verum marking. Consider first (58).

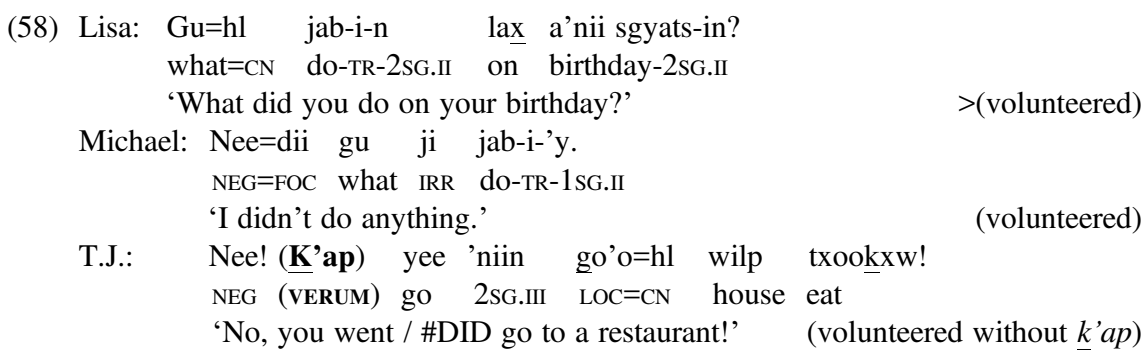

Michael's utterance expresses the proposition that he didn't do anything on his birthday, which entails that he didn't go to a restaurant. Hence, he is clearly committed to the proposition that he didn't go to a restaurant. This licenses the use of $k^{\prime}$ 'ap in T.J.'s response, in accordance with the proposed analysis of $k^{\prime}$ ap. ${ }^{15}$ Notice, however, that verum in the English translation of T.J.'s utterance is infelicitous. ${ }^{16}$ (59) is a similar case:

\footnotetext{
${ }^{15}$ There is admittedly some speaker variation here: one consultant rejected $k^{\prime} a p$ in (58), saying "No. Except if he [Michael] keeps saying 'I didn't do anything!"” However, the acceptance of $\underline{k}^{\prime} a p$ in the relevant type of situation is not limited to one speaker or one occasion, but has at least some level of generality, as confirmed by other data below.

${ }^{16} \mathrm{An}$ anonymous reviewer points out that with contrastive topic intonation (i.e., not with a verum interpretation), T.J.'s utterance in (58) can be acceptable (see e.g., Wilder 2013 on contrastive topic uses of stressed $d o$ ). As in most of Wilder's examples of contrastive topic do, T. J.'s utterance is (in my judgment) strongly preferred to begin with 'Well...' under this reading.
} 
(59) Context: Michael is talking about his pet, and Lisa doesn't know what kind of animal it is.

$\begin{array}{llll}\text { Lisa: } & \text { Agu=t } & \text { Fluffy? } \\ & \text { what=PN } & \text { Fluffy } \\ & \text { 'What is Fluffy?' } & \\ \text { Kyra: } & \text { Os=t } & \text { Fluffy. } & \\ & \text { dog=PN } \quad \text { Fluffy } & \\ & \text { 'Fluffy's a dog.' } & \\ \text { Michael: } & \text { Nee, (k'ap) lelt=t } & \text { Fluffy. } \\ & \text { NEG (VERUM) } & \text { snake=PN } & \text { Fluffy } \\ & \text { 'No, Fluffy's / \# Fluffy IS a snake.' }\end{array}$

Kyra's assertion that Fluffy is a dog clearly commits her to the proposition that Fluffy isn't a snake; it is therefore unsurprising that $\underline{k}^{\prime} a p$ is felicitous in Michael's response. Again, however, English does not pattern in a similar fashion; verum is disallowed. And again in (60), $k^{\prime}$ ap is licensed because the addressee is committed to the proposition that Clarissa gives part of the speech in English - yet verum is inappropriate in English in this context.

(60) Context: It's a feast, and the MC knows that Clarissa is white and thinks she might not be able to give our table's speech in the language. He tells her: "You can say part of it in Giyanimx and part of it in English." She replies:

(K'ap) ksax Giyanimx hasag-a'y dim hoo[-i]-'y=ist. (VERUM) only Giyanimx want-1sG.II PROSP use[-TR]-1sG.II=QUDD 'I (\#DO) want to speak only Giyanimx.'

(Gutzmann et al. 2020)

I propose that the difference between the languages is that English verum marking requires givenness of the prejacent proposition, while Gitksan verum marking does not. In Gitksan, (58)-(60) are fine with $k^{\prime}$ 'ap because in each case, the addressee is committed to the negation of $k$ 'ap's prejacent, through a simple entailment relation: doing nothing entails not going to a restaurant, being a dog entails not being a snake, and saying part of a speech in English entails not speaking only Giyanimx. In English, however, it is not sufficient for the prejacent's negation to be entailed by previous discourse commitments; the prejacent itself must have been given in prior discourse (see Gutzmann et al. 2020, a.o., on the givenness requirement on Germanic verum, and Rochemont 2016; Gyuris (2020); Wagner (2020) for recent general overviews of givenness). In the contexts of (58)-(60), the prejacent has not already been mentioned in the discourse, therefore English verum marking is infelicitous. We return to the theoretical implications of this in the next section.

\section{CONCLUSIONS}

In this article I have argued that the Gitksan preverbal element $k^{\prime}$ ap is a marker of verum, and I have provided a discourse management analysis of its effects. I looked at ten types of discourse context and showed that the analysis predicts when $k^{\prime}$ ap is straightforwardly felicitous, when it is completely ruled out, and when it is allowed but requires prior controversy within the discourse. 
In this final section, I compare the analysis proposed here with analyses of similar phenomena in other languages, and outline some implications and directions for future research.

\subsection{Comparison with other analyses}

There is active theoretical debate about the best analysis of verum. As mentioned earlier, the two main families of approaches are focus-based analyses and discourse management operator analyses. The analysis proposed here is similar to discourse management approaches like that of Repp (2013) and Romero (2015); it is particularly similar (though not identical) to recent proposals by Gutzmann et al. (2020). However, the current study has identified a new cross-linguistic difference in the behaviour of verum, which I argue provides support for a non-focus-based analysis.

According to focus-based analyses, verum involves focus on an abstract operator (Höhle 1992). A typical instantiation of this idea holds that there is focus on a covert element (present in every finite sentence) which marks the prejacent proposition as true; focusing this element invokes a contrast with the salient alternative, the negation of the prejacent. Approaches of this type include Büring (2006) and Stommel (2011, 2012) for German, Zimmermann and Hole (2008) for a range of languages, Leonetti and Escandell-Vidal (2009) for Spanish, and Bennett et al. (2015) for Irish. ${ }^{17}$

An alternative set of analyses assign the effect of verum not to focus but to a dedicated operator, which is present only when verum emphasis is desired. ${ }^{18}$ Analyses along these lines include those of Romero and Han (2004), Gutzmann and Castroviejo Miró (2011), Gutzmann (2012), Repp (2013), Romero (2015), among others. Romero (2015), adapting ideas from Romero and Han (2004), proposes that verum contributes the use-conditional content in (61). This is paraphrased as ' $\mathrm{x}$ is sure that, in all the worlds satisfying x's conversational goals, $p$ is added to the Common Ground. ${ }^{19}$

(61) Common Ground-management content of verum:

$\lambda \mathrm{p}_{<\mathrm{s}, \mathrm{t}>} . \lambda \mathrm{w}_{\mathrm{s}} . \forall \mathrm{w}^{\prime} \in \operatorname{Epi}_{\mathrm{x}}(\mathrm{w})\left[\forall \mathrm{w}^{\prime \prime} \in \operatorname{Conv}_{\mathrm{x}}\left(\mathrm{w}^{\prime}\right)\left[\mathrm{p} \in \mathrm{CG}_{\mathrm{w}}{ }^{\prime}\right]\right]$

(Romero 2015:503)

Another version of this type of analysis relates verum to the Question Under Discussion (QUD); for example, Gutzmann and Castroviejo Miró (2011:160) argue that verum is an instruction from the speaker to downdate (resolve) the QUD. ${ }^{20}$

${ }^{17}$ See also Samko (2016) and Goodhue (2018) for focus analyses of English verum. A slightly different version, that of Lohnstein $(2012,2016,2018)$, is that verum marking represents focus on the sentence mood.

${ }^{18}$ Gutzmann (2012), Gutzmann et al. (2020) contrast the 'FAT' ('focus accent thesis') with the 'LOT' ('lexical operator thesis').

${ }^{19}$ In a similar vein, Repp $(2009,2013)$ argues that verum signals the maximum degree of strength of a speech act's sincerity conditions.

${ }^{20}$ A slightly similar non-focus analysis is provided by AnderBois (2011), who concentrates on verum in questions and assertions with preposed negation. Working within an inquisitive semantics framework, he proposes that verum suppresses the inquisitive contribution of the sentence. As a result, there is 'emphasis on the informative, truth-conditional meaning component' (AnderBois 2011:178). 
One reason I have adopted a lexical operator analysis of verum, rather than a focus-based one, is that in Gitksan (unlike in English or German), there is no similarity between how verum is marked and how focus is marked. Constituent focus is marked by A'-movement to sentence-initial position (Davis and Brown 2011, Bicevskis et al. 2017), and predicate focus is either not marked at all, or optionally marked with the exhaustive focus element k'am (Martin 2019). It therefore seems simpler to take the facts at face value: there is a preverbal element which appears only in verum contexts, and which has detectable discourse effects. The obvious thing to do is to assign those effects to the lexical entry of this morpheme. ${ }^{21}$

The second reason why I believe the Gitksan data support a discourse management analysis, rather than a focus-based one, relates to the givenness difference between Gitksan $k^{\prime}$ ap and English verum marking, discussed in the previous section. As is well-known, focus and (non-)givenness are related semantic notions, though not reducible to each other. They are also prosodically similar in English: focused material is prosodically prominent, while given material is prosodically reduced (Schwarzschild 1999, among many others). Given this, we may speculate about the link between verum, givenness and focus as follows (this is adapted from Gutzmann et al. 2020).

Suppose that English verum includes a givenness requirement: the prejacent $p$ must be given in the discourse. The lexical material in the prejacent would then be expected to all be de-accented. However, since there must be a nuclear pitch accent in every utterance, this pitch accent is realized on a left-periphery element such as an auxiliary $D O$. This approach would allow us to account for the parallel realisation of verum and focus in English, without either analyzing English verum as involving focus, or resorting to an accidental homonymy of focus marking and verum marking.

In Gitksan, on the other hand, there is no givenness requirement on verum $/ k^{\prime} a p$. Therefore, no focus-like phenomena are involved in verum marking. The difference between the languages reduces to the slightly different lexical semantics of their respective discourse management operators. This allows a basically uniform approach to the semantics of verum cross-linguistically.

My proposal about the discourse conditions on Gitksan verum differs subtly from previous discourse-management-based proposals. For example, it differs from Romero's in (61), according to which verum is felicitous whenever the speaker is sure that the prejacent should enter the Common Ground. Under Romero's approach, the effects of 'bias' with verum arise indirectly, as an epistemic implicature. For example, in a polar question containing verum, the speaker 'wonders [...] whether the addressee has fully convincing evidence for adding $p$ to the CG' (Romero 2015:506). This leads to the implicature that there is doubt about $p$. Roughly, then, the approach put forward here hardwires into the use-conditions what Romero's

${ }^{21}$ An anonymous reviewer correctly points out that this is not yet a conclusive argument, since there could be independent differences between verum focus and other types of predicate focus. The reviewer notes that further relevant evidence would include whether verum $\left(k^{\prime} a p\right)$ and predicate focus $\left(\underline{k}^{\prime} a m\right)$ behave in a parallel fashion with respect to co-occurrence with other markers of focus, such as fronting of nominal arguments. Some of the questions about multiple focus and $k^{\prime} a p$ are addressed by Gutzmann et al. (2020), but there is more work to be done. 
analysis derives via implicature. Conversely, the current analysis can derive as an implicature what Romero hardwires into the use-conditions: that the speaker is sure $p$ should enter the CG. Intuitively, a speaker who utters VERUM ( $p$ ) signals that they are aware that an interlocutor believes $\neg p$, but they go ahead and assert $p$ anyway. The assertion of $p$ in the face of disagreement or controversy implicates that they are sure that $p$ is true.

At this point, it is difficult to make a knock-down argument for hardwiring controversy, as opposed to speaker certainty. However, a potential advantage of the current analysis is that it is statable by referring to the commitment space development (the representation of the current state of the discourse). As such, it makes quite concrete predictions about when verum is and is not felicitous.

The current proposal also seems to fit the Gitksan data better than Gutzmann and Castroviejo Miró's (2011) QUD-based analysis, which appears to over-generate verum in answers to neutral polar questions (because any answer to a polar question downdates the QUD).

\subsection{Implications and future research}

One interesting consequence of viewing $\underline{k}$ 'ap as verum relates to the way Gitksan expresses the concept of 'but'. There is no dedicated connective for this, and English sentences containing 'but' are often translated using $k$ 'ap plus the ordinary clausal conjunction $i i$ 'and', as in (62).

$$
\begin{array}{lllllll}
\text { Da'akxw-i-'y } & \text { ji } & \text { hahla'alsd-'y ky'oots, } & \text { ii } & \text { ap } & \text { nee=dii wil-'y. } \\
\text { CIRC.POSS-TR-1sG.II } & \text { IRR } & \text { work-1sG.II yesterday } & \text { CCNJ } & \text { VERUM } & \text { NEG=FOC } & \text { do-1sG.II } \\
\text { 'I was able to work yesterday, but I didn't.' } & & & &
\end{array}
$$

Viewing $k^{\prime}$ ap as verum allows us to account for its use in cases like (62) compositionally: this really is just conjunction plus verum, and the inherently contrastive nature of verum explains why a language without a dedicated 'but'-conjunction would frequently add verum to its plain conjunction. This also correctly predicts that k'ap will not always be present in cases where English uses 'but', and conversely that it will be present in some cases where English uses 'and' or no conjunction at all; these facts are illustrated in (63)-(64) respectively.

(63) Context: You put some water in the fridge to get cool.

$\begin{array}{llllll}\mathrm{Sgi} & \operatorname{dim} \text { gwineekxw=hl aks tun, ii }\left(\text { ap) nee-d=is. }{ }^{22}\right. \\ \text { CIRC.NECESS } & \text { PROSP } & \text { cold }=\mathrm{CN} & \text { water DEM.PROX CCNJ } & \text { (VERUM) } & \text { NEG-3.II=QUDD } \\ \text { 'The } & & \end{array}$

'The water should be cold by now, but it isn't.'

(volunteered without $a p$ )

\footnotetext{
${ }^{22}$ The morpheme glossed as 3.II in this negative ellipsis construction has properties of both a series II pronoun (since the antecedent of the ellipsis is intransitive), and also of a series I pronoun (since it is behaving as a clitic). This problem was noticed by Davis and Brown (2014), who write that 'Negation (nee) in negative ellipsis always appears with an (unexpected) suffixed $-t$, whose provenance is mysterious (it is not identifiable with either Series I third person clitic $t$ or Series II third person suffix $-t)$.' Thanks to an anonymous reviewer for asking about this, and to Henry Davis for discussion.
} 
Consultant's comment: "When you put an ap in there, it's 'Ii ap NEE dis!' [gestures, speaks more emphatically and louder] You're kind of upset about it."

(64) Context: The Canucks were down 1-0 at the end of the first period. Then they lost focus and started playing badly.

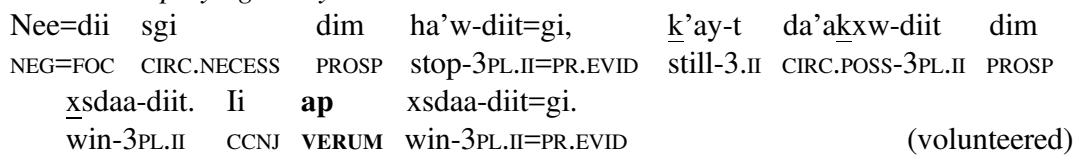

'They shouldn't have given up, because they could have still won - and they did win.'

I conclude by pointing out some issues for future research. One of these involves verum in embedded clauses, which I have not addressed here. Much of the literature similarly sets these aside; see Gutzmann (2012), Lohnstein (2016) for some discussion.

A second empirical domain for future research is $w h$-questions. Verum is acceptable inside wh-questions in English and German (e.g., Höhle 1992:118). $K^{\prime}$ ap has been accepted in $w h$-questions by all my consultants on at least one occasion, but it has never been volunteered, and it is sometimes rejected. There is also variation in judgments about where $k^{\prime}$ ap should appear syntactically (sentence-initially, between the $w h$-word and the ergative extraction marker, or between the ergative extraction marker and the verb). One example is given in (65), but further targeted empirical testing is required.

(65) Context: We see the dog lying there injured.

Me: Nee $=$ dii $[=\mathrm{t}] \quad$ hlo'oxs $\quad$ Michael $=\mathrm{hl}$ os ii hoox $=$ dii nee $=\mathrm{dii}=\mathrm{n}$

NEG=FOC[=3.I $] \quad$ kick[-3.II $] \quad$ Michael $=\mathrm{CN} \quad \operatorname{dog} \quad \mathrm{CCNJ} \quad$ also=FOC $\quad$ NEG $=\mathrm{FOC}=1 . \mathrm{I}$ hlo'oxs $=$ hl os.

$\operatorname{kick}[-\overline{3} . \mathrm{II}]=\mathrm{CN} \quad \operatorname{dog}$

'Michael didn't kick the dog and I also didn't kick the dog.'

You: Naa (k'ap) an=t hlo'oxs[-t]=hl os?

who (VERUM) AX=3.I $\operatorname{kick}[-3 . \mathrm{II}]=\mathrm{CN}$ dog

'Well, who DID kick the dog?'

(volunteered without $\underline{k}^{\prime} a p$; adapted from Höhle 1992:113)

Consultant's comment on $k$ 'ap-version: "Yeah. $K$ 'ap is 'Who ... really ... did ... this?"”

Imperatives are another clause type for future research. $K^{\prime}$ ap is not volunteered in imperatives, and there are variable judgments about its acceptability. The generalization seems to be that $k^{\prime} a p$ is acceptable in imperatives only in extreme cases of frustration or opposition. It is consistently dispreferred or rejected in contexts such as (66) (adapted from Gutzmann 2012:30), but is more likely to be accepted in contexts of repeated commands, as in (67). In this, $k$ 'ap seems to behave in a parallel fashion to verum marking in German, as reported by Gutzmann (see also Höhle 1992:118), but unlike English, which disallows verum in imperatives.

$\begin{array}{lllll}\text { (66) A: } & \text { Sim } & \text { k'yaa } & \text { gwalgwax } & \text { 'nii'y. } \\ & \text { true } & \text { extremely } & \text { thirsty } & \text { 1sG.III } \\ & \text { 'I'm so thirsty!' } & & \end{array}$

(volunteered) 


\begin{tabular}{|c|c|c|c|c|c|}
\hline \multirow[t]{2}{*}{ B1: } & $\begin{array}{l}\text { Gyup, } \\
\text { go.ahead }\end{array}$ & $\begin{array}{l}\text { (\#ap) } \\
\text { (\#VERUM) }\end{array}$ & $\begin{array}{l}\text { aks }=\mathrm{hl} \\
\text { drink }=\mathrm{CN}\end{array}$ & $\begin{array}{l}\text { ligi } \\
\text { DWID }\end{array}$ & $\begin{array}{l}\text { agwi! } \\
\text { what }\end{array}$ \\
\hline & 'Drink so1 & nething!' & & & (volunteered without $a p$ ) \\
\hline \multirow[t]{2}{*}{ B2: } & & $\mathrm{aks}=\mathrm{hl}$ & ligi & agwi! & \\
\hline & $\begin{array}{l}\text { VERUM } \\
\text { 'Drink sol }\end{array}$ & $\begin{array}{l}\text { drink }=\mathrm{CN} \\
\text { mething } 1\end{array}$ & DWID & what & $\operatorname{mann} 2012 \cdot 30)$ \\
\hline
\end{tabular}

Consultant's comment on B2: "You can, but the ap is not necessary. Maybe it's too forward or demanding tone."

(67) Context: You ask Aidan to fetch some water. Aidan ignores you. You say it again, and he ignores you again. You say it again:

\begin{tabular}{|c|c|c|}
\hline $\begin{array}{ll}\text { S1: } & \text { (Ap) } \\
& \text { (VERUM) }\end{array}$ & $\begin{array}{ll}\text { go'o }=\text { hl } & \text { aks } \\
\text { fetch }=\text { CN } & \text { water }\end{array}$ & $\begin{array}{l}\text { loo-'y! } \\
\text { OBL-1sG.II }\end{array}$ \\
\hline
\end{tabular}
S2: (??Ap) suu=hl aks loo'y Aidan! (vERUM) fetch $=\mathrm{CN}$ water OBL-1sG.II Aidan 'GET me some water, Aidan!' (volunteered without ap) Consultant's comment on S2 with ap: "Not really ... it's not appropriate ... the ap isn't necessary, but it might be appropriate if the speaker is saying it for the second or third time."

In one available discussion of verum in imperatives, Gutzmann and Castroviejo Miró (2011) propose that uttering an imperative raises the question of whether the addressee fulfills the order. For them, a verum-marked imperative signals that the speaker wants that question to be downdated. In the current analysis, a verummarked imperative could signal that the speaker believes some interlocutor is committed to the proposition that the addressee will not fulfill the order.

Finally, future research should follow up on an intriguing type of data provided by Margaret Anderson (p.c.) for the related language Sm'algyax. Anderson observes that while many of the corpus examples of Sm'algyax $k$ 'ap seem to fit the generalizations given here for Gitksan, a subset of cases appear to contradict them. These involve the initial sentences of texts; one example is given in (68):

(68) Asda wagayt gyik'ooł ada ḱ 'ap ławila waalsga Ginax'angiik at haba 'naka Stakiin. 'Many long years ago the people of the Ginax'angiik always went into the direction of the Stikine River.'

(William Beynon ms. 040: Na Wilawaals Seeks asga Stakiin (line 1))

The analysis presented here does not predict the presence of a verum marker in the first sentence of a narrative. We do not have access to a large corpus of such narratives in Gitksan, but very preliminary attempts to elicit similar examples suggest that $k^{\prime} a p$ might indeed be acceptable here, just like in Sm'algyax. The narrativeinitial examples tested so far were accepted by a consultant who nevertheless continues to robustly reject $k^{\prime} a p$ in the discourse-initial contexts discussed in section 3.1. If this pattern holds more generally, I will be forced to conclude that there is something special about the opening lines of traditional stories, such that for some reason they do not behave like pure 'out-of-the-blue' contexts. Further investigation is clearly required. 
This article adds to a growing body of work which investigates the properties of discourse-sensitive elements using fieldwork data. It adds to the cross-linguistic landscape of verum constructions, by showing in detail that verum can be conveyed by an explicit morpheme rather than by focus-marking (see the references in section 5.1 for this proposal for some European languages, and Gutzmann et al. 2020 for the Chadic languages Bura and South Marghi). Finally, I hope that the comprehensive set of fieldwork tests illustrated in section 3 (see also Zimmermann and Hole 2008) will be useful to future researchers investigating verum(-like) elements in a range of languages.

\section{REFERENCES}

Adams, C., B. Anderson, B. Andreotti, L. Koh, J. Makepeace, and S. Park. 2016. 'Getting to the root of the problem' storyboard. Ms., University of British Columbia.

AnderBois, Scott. 2011. Issues and alternatives. Doctoral dissertation, University of California at Santa Cruz.

Bennett, Ryan, Emily Elfner, and Jim McCloskey. 2015. Prosody, focus and ellipsis in Irish. Language 95:66-106.

Berman, Ruth A., and Dan Isaac Slobin. 1994. Relating events in narrative: A cross-linguistic developmental study. Hillsdale, NJ: Erlbaum.

Bicevskis, Katie, Henry Davis, and Lisa Matthewson. 2017. Quantification in Gitksan. In Handbook of quantification in natural languages Vol. II., ed. Denis. Paperno and Edward L. Keenan, 281-382. Dordrecht: Springer.

Boas, Franz. 1911. Tsimshian. In Handbook of North American Indian Languages. Part 1. Bureau of American Ethnology. Bulletin 40, Part 1, 283-422. Washington: Government Office.

Bochnak, M. Ryan, and Lisa Matthewson. 2015. Methodologies in Semantic Fieldwork. Oxford: Oxford University Press.

Bochnak, M. Ryan, and Lisa Matthewson. 2020. Techniques in complex semantic fieldwork. Annual Review of Linguistics 6:261-283.

Büring, Daniel. 2006. Intonation und Informationsstruktur. Grammatik und darüber hinaus [Intonation and Information Structure. Grammar and Beyond]. In Text - Verstehen[Text - Understanding], ed. Hardarik Blühdorn, Eva Breindl, and Ulrich H. Waßner, 144163. Berlin: de Gruyter.

Burton, Strang, and Lisa Matthewson. 2015. Targeted construction storyboards in semantic fieldwork. In Methodologfies in Semantic Fieldwork, ed. M. Ryan Bochnak and Lisa Matthewson, 135-156. Oxford: Oxford University Press.

Chafe, Wallace L., ed.. 1980. The pear stories: Cognitive, cultural, and linguistic aspects of narrative production. Norwood, NJ: Ablex.

Cohen, Ariel, and Manfred Krifka. 2014. Superlative quantifiers and meta-speech acts. Linguistics and Philosophy 37(1):41-90.

Danckaert, Lieven. 2013. Quidem as a marker of emphatic polarity. Transactions of the Philological Society 112(1):97-138.

Davis, Christopher, and Eric McCready. 2016. Expressives in questions. In Proceedings of SALT 26, 1119-1138. Washington and Cornell: LSA Open Journal Systems and CLC Publications. 
Davis. Henry, and Jason Brown. 2014. Focus and negative ellipsis in Gitksan. Paper presented at the 29th International Conference on Salish and Neighbouring Languages, Coeur D'Alene.

Davis, Henry, and Jason Brown. 2011. On A'-dependencies in Gitksan. In Papers for the 46th International Conference on Salish and Neighbouring Languages, UBC Working Papers in Linguistics 30:43-80.

Dunlop, Britt, Suzanne Gessner, T. Herbert, and A. Parker. 2018. Report on the status of B.C. First Nations languages. Brentwood Bay, BC: First Peoples' Cultural Council.

Farkas, Donka F., and Kim B. Bruce. 2010. On reacting to assertions and polar questions. Journal of Semantics 27(1):81-118.

Goodhue, Daniel. 2018. A minimal theory of verum focus and context dependent bias in questions. In Proceedings of the North East Linguistics Society 48 Vol. 2, ed. Sherry Hucklebridge and Max Nelson, 1-10. Amherst, MA: GLSA.

Gunlogson, Christine. 2003. True to form: Rising and falling declaratives as questions in English. New York: Routledge.

Gunlogson, Christine. 2008. A question of commitment. Belgian Journal of Linguistics 22(1): 101-136.

Gutzmann, Daniel. 2012. Verum - Fokus - Verum-Fokus? Fokus-basierte und lexikalische Ansätze[Verum - focus - verum focus? Focus-based and lexical approaches]. In Wahrheit - Fokus - Negation[Truth Focus - Negation], ed. Hardarik Blühdorn and Horst Lohnstein, 67-103. Hamburg: Buske.

Gutzmann, Daniel, and Elena Castroviejo Miró. 2011. The dimensions of verum. In Empirical issues in syntax and semantics 8, ed. Olivier Bonami and Patricia Cabredo-Hofherr, 143-165.

Gutzmann, Daniel, K. Hartmann, and Lisa Matthewson. 2016. Cross-linguistic evidence that verum is not focus. Paper presented at the Deutsche Gesellschaft für Sprachwissenschaft[German Linguistic Society], Universität Konstanz.

Gutzmann, Daniel, K. Hartmann, and Lisa Matthewson. 2020. Verum focus is verum, not focus: Cross-linguistic evidence. Glossa: A Journal of General Linguistics 5(1):51,148. <https://doi.org/10.5334/gjgl.347>.

Gyuris, Beata. 2009. Quantificational contrastive topics with verum/falsum focus. Lingua 119: $625-649$.

Gyuris, Beata. 2020. Information structure. In The Blackwell Companion to Semantics, ed. Daniel Gutzmann, Lisa Matthewson Cecile Meier, Hotze Rullmann and Thomas Ede Zimmermann. Oxford: Wiley-Blackwell.

Hacquard, Valentine, and Jeffrey Lidz. 2018. Children's attitude problems: Bootstrapping verb meaning from syntax and pragmatics. Mind and Language 2018:1-24.

Hartmann, Katharina. 2013. Verum intervention effects in Chadic languages. Lingua 136: $103-124$.

Hartmann, Katharina, Peggy Jacob, and Malte Zimmermann. 2008. Asymmetric focus marking in Bura. In Interdisciplinary studies on information structure 10. Working Papers of the SFB 632 10, ed. Shinshiro Ishihara, Michaela Schmitz and Anne Schwarz, 45-92. Potsdam: Universitätsverlag Potsdam.

Hetland, J. 1992a. Polaritätsfokus, VERUM-fokus, Kopffokus[Polarity focus, verum focus, head focus]. STUF: Language Typology and Universals 45(1-4):3-16.

Hetland, J. 1992b. Verum-Fokus: Fakten, Hypothesen, Fragen und nochmals Fragen[Verum focus: Facts, hypotheses, questions and more questions]. Sprache und Pragmatik [Language and Pragmatics] 25:11-27. 
Hindle, Lonnie, and Bruce Rigsby. 1973. A short practical dictionary of the Gitksan language. Northwest Anthropological Research Notes 7:1-60.

Höhle, Tilman N. 1992. Über Verum-Fokus im Deutschen[On verum focus in German]. In Informationsstruktur und Grammatik[Information Structure and Grammar], ed. Joachim Jacobs, 112-141. Opladen: Westdeutscher Verlag.

Krifka, Manfred. 2008. Basic notions of information structure. Acta Linguistica Hungarica 55: 243-276.

Krifka, Manfred. 2015. Bias in commitment space semantics: Declarative questions, negated questions, and question tags. Proceedings of SALT 25: 328-345. Washington: LSA Open Journal Systems.

Krifka, Manfred. 2017. Negated polarity questions as denegations of assertions. In Contrastiveness in information structure, alternatives and scalar implicatures, ed. Chungmin Lee, Ferenc Kiefer and Manfrd Krifka, 359-398. Dordrecht: Springer.

Leonetti, Manuel, and Victoria Escandell-Vidal. 2009. Fronting and verum focus in Spanish. In Focus and background in Romance Languages, ed. Andreas Dufter and Daniel Jacob, 155-204. Amsterdam: John Benjamins.

Littell, Patrick. 2016. Focus, predication, and polarity in Kwak'wala. Doctoral dissertation, University of British Columbia.

Lohnstein, Horst. 2012. Verumfokus - Satzmodus - Wahrheit[Verum focus - sentence mood truth]. In Wahrheit - Fokus - Negation[Truth - Focus - Negation], ed. Hardarik Blühdorn and Horst Lohnstein, 31-66. Hamburg: Helmut Buske Verlag.

Lohnstein, Horst. 2016. Verum focus. In The Oxford Handbook of Information Structure, ed. Caroline Féry and Schinichiro Ishihara, 290-313. Oxford: Oxford University Press.

Lohnstein, Horst. 2018. Verum focus, sentence mood, and contrast. In Linguistik Aktuell / Linguistics Today 240, The grammatical realization of polarity contrast: Theoretical, empirical, and typological approaches, ed. Christine Dimroth and Stefan Sudhoff, 55-87.

Malamud, Sophia, and Tamina Stephenson. 2015. Three ways to avoid commitments: Declarative force modifiers in the conversational scoreboard. Journal of Semantics 32 (2):275-311.

Martin, Katie 2019. Exhaustivity and focus marking in Gitksan. In Papers for the International Conference on Salish and Neighbouring Languages 54, ed. Daniel K. E. Reisinger and Gloria Mellesmoen, 101-109, Vancouver, BC: UBCWPL.

Matthewson, Lisa. 2004. On the methodology of semantic fieldwork. International Journal of American Linguistics 70:369-415.

Matthewson, Lisa. 2013. Gitksan Modals. International Journal of American Linguistics 79: 349-394.

Matthewson, Lisa. 2019. Aren't negative questions in Gitksan biased? Paper presented at SPAGAD-1 Speech acts in grammar and discourse. Leibniz-Zentrum Allgemeine Sprachwissenschaft, Berlin.

Peterson, Tyler. 2010. Epistemic modality and evidentiality in Gitksan at the semantics-pragmatics interface. Doctoral dissertation, University of British Columbia.

Portner, Paul. 2004. The semantics of imperatives within a theory of clause types. In Proceedings of SALT 14, ed. Kazuha Watanabe and Robert B. Young, 235-252. Ithaca, NY: CLC Publications.

Potts, Christopher. 2005. The Logic of Conventional Implicature. Oxford: Oxford University Press.

Repp, Sophie 2009. Negation in Gapping. Oxford: Oxford University Press. 
Repp, Sophie. 2013. Common Ground management: Modal particles, illocutionary negation and VERUM. In Beyond expressives. Explorations in use-conditional meaning, ed. D. Gutzmann and H.-M. Gärtner, 231-274. Leiden: Brill.

Rigsby, Bruce. 1986. Gitksan grammar. Ms., University of Queensland.

Rochemont, Michael. 2016. Givenness. In The Oxford Handbook of Information Structure, ed. Caroline Féry and Shinochiro Ishihara, 41-63. Oxford: Oxford University Press.

Romero, Maribel. 2015. High negation in subjunctive conditionals and polar questions. In Proceedings of Sinn und Bedeutung 19, ed. Eva Csipak and Hedde Zeijlstra, 499-516. Göttingen: Georg-August-University Göttingen.

Romero, Maribel, and Chung-Hye Han. 2004. On negative yes/no questions. Linguistics and Philosophy 27:609-658.

Samko, Bern. 2016. Syntax and information structure: The grammar of English inversions. Doctoral dissertation, University of California at Santa Cruz.

Schwarz, Anne. 2010. Verb-and-predication focus marking in Gur. In The expression of information structure: A documentation of its diversity across Africa, ed. Ines Fiedler and Anne Schwarz, 287-314. Amsterdam: John Benjamins.

Schwarzschild, Roger. 1999. GIVENness, AvoidF, and other constraints on the placement of accent. Natural Language Semantics 7(2):141-177.

Stalnaker, Robert. 1978. Assertion. In Pragmatics. Syntax and Semantics 9, ed. Peter Cole, 315-332. New York: Academic Press.

Stommel, Hildegard. 2011. Verum-Fokus im Deutschen[Verum Focus in German]. Marburg: Tectum.

Stommel, Hildegard. 2012. Verum-Fokus als Kontrast-Fokus[Verum focus as contrastive focus]. In Wahrheit - Fokus - Negation[Truth - Focus - Negation], ed. H. Blühdorn and Horst Lohnstein, 15-29. Hamburg: Buske.

Tarpent, Marie-Lucie. 1987. A grammar of the Nisgha language. Doctoral dissertation, University of Victoria.

Tonhauser, Judith. 2012. Diagnosing (not-)at-issue content. Proceedings of Semantics of Under-represented Languages of the Americas (SULA) 6, 239-254. Amherst, MA: GLSA.

Tonhauser, Judith, and Lisa Matthewson. 2016. Empirical evidence in research on meaning. Ms., The Ohio State University / University of British Columbia. $<\mathrm{https}$ ://ing.auf.net/lingbuzz/002595>.

Wagner, Michael. 2020. Prosodic focus. In The Blackwell Companion to Semantics, ed. Daniel Gutzmann, Lisa Matthewson, Cécile Meier, Hotze Rullmann and Thomas Ede Zimmermann. Oxford: Wiley-Blackwell.

Wilder, Chris. 2013. English 'emphatic do'. Lingua 128:142-171.

Zimmermann, Malte, and Daniel Hole. 2008. Predicate focus, verum focus, verb focus. Similarities and difference. Talk presented at the Potsdam-London IS Meeting. 